suing options other than the national university. The fact that there are more private than public secondary schools in Montevideo signals a change in postsecondary education as well since students historically have chosen to attend public rather than private secondary schools to facilitate their entry into the national university. Correspondingly, the number of students in private higher education is growing. The number of students graduating from just two private universities (ORT and Catholic University) in 1996 was 216 , while 2,724 graduated from the public university.

\section{The Catholic Church has had less of an impact on Uruguay than on other Latin American countries.}

\section{Government Regulation}

A third factor limiting privatization is the barriers created by government. The national university has jealously guarded its position within higher education-even in relation to other state-run educational institutions. For example, the national normal school, which is responsible for primary and secondary school teacher preparation, is not a part of the university system and has long been viewed as the competition by the university's College of Education. Not surprisingly, the national university has also opposed the recognition of private universities and believes that if they must exist, they should be regulated by an autonomous body-namely, by the national university itself.

At the present time, the government regulates private tertiary education by means of a special eight-person com- mittee. However, the national university still exerts an inordinate degree of control: only two seats go to private universities, whereas three go to the national university outright and another three to government administrators who are alumni and former employees of the state university. The national university openly admits that it promoted the law regulating privates and that its ongoing involvement in the process is "without bias." The Ministry of Education, which is usually headed by a former rector of the national university, has put several conditions on the recognition of private universities that discourage the presence of foreign faculty and the existence of specialized institutions. In 1995, on the 10th anniversary of the founding of Catholic University, an additional 20 institutions had already been approved by the Ministry of Education, while up to 15 more were seeking approval. Nevertheless, in the latest (1997) Ministry of Education report only two private institutions are listed under postsecondary education.

\section{Conclusion}

Of the three factors shaping private higher education in Uruguay, only the third, government barriers, has remained unchanged. The Catholic Church has reasserted its traditional influence in education. Private higher education enrollments continue to increase as dissatisfaction with public schooling grows. The Uruguayan education system has changed, and it is time for the government to reflect this new reality. The government must take steps to depoliticize the recognition process, reducing the role of the national university. As former President Lacalle noted, the government must get out of the business of private tertiary education; the tutelage of the state should end. Private institutions must have sufficient autonomy from external controls to respond to local needs. They must not be burdened by the bureaucracy that has handicapped the public university.

\title{
Challenges for Public Higher Education in Uruguay
}

\section{Rodrigo Arocena and Judith Sutz}

Rodrigo Arocena and Judith Sutz are on the staff of the Universidad de la República, Montevideo, Uruguay. E-mail: <roar@fcien.edu.uy>.

$U_{\mathrm{p}}$ ruguay is a small South American country with a population of 3.2 million. From the end of the 19th century it was transformed by a process of massive immigration, mainly from Europe. Since the early 20th century, education has been a tool for social progress, as reflected in the early extension of free public basic education. While much has changed, some things survive-the welfare state, for instance, which the people have not al-

lowed to disappear completely. Uruguay is now the least unequal country in Latin America in terms of income distribution. Education continues to be a high priority for the Uruguayan people, and the country is second only to Argentina, in Latin America, in terms of the proportion of the age group entering university.

Until 1985, Uruguay had only one university-a public one: the Universidad de la República (UR). Nowadays there are a number of private universities, but the bulk of Uruguayan higher education continues to be represented by the UR. It is a big university in Latin American terms, with 60,000 students. The vast majority of them study in the capital, Montevideo, which has a high concentration of higher education institutions.

The distinctive characteristics of the UR are that it is totally free of charge and students may choose what to study, since there are no limitations on admissions or en- 
trance examinations to any part of the university-including the medical school. UR is also the only institution of higher education that offers teaching in all the main professional fields, along with undergraduate courses in the arts, humanities, and basic sciences. The UR budget comes entirely from the state. Only recently have research and consulting contracts begun to have some significance in budgetary terms.

The UR belongs to the important historical tradition of the Latin American university reform movement. Thus the UR has full autonomy for choosing its senior administrators, and the governance of the university lies with its "citizenry"- the teachers, graduates, and students. The university's three missions are teaching, research, and " $\mathrm{ex}$ tension" (i.e., cultural diffusion and technical assistance to support the most deprived sectors of the population). The social engagement of the public university was greatly fostered by the student movement. Since 1950, this has led to close relationships with trade unions and other social movements and strong enmities with right-wing governments.

In the early 1970s, as part of a wave that affected not only Uruguay, democratic rule was overturned by a military dictatorship that lasted until 1985. This had major consequences for public higher education, for the military government expelled the senior administration of the UR, dismissed hundreds of teachers, banned open discussion and free association, and caused the massive migration of scientists and researchers. Many programs fell into academic decline, research activities ceased in several areas, and for over 10 years the research infrastructure was not updated. On the other hand, the people's fight for democracy found strong support among UR students and many of its faculty, which reinforced the view that the public university is the "university of the country."

The situation for the UR has greatly improved, but major difficulties, both old and new, affect its performance. The old problems are diverse. The bulk of the student population continues to come from the middle or upper classes, in spite of efforts to facilitate the entrance of working-class young people. The "massiveness" of the UR's structure complicates and slows down the process of change; this is particularly the case with the professional schools, whose organization hampers interdisciplinary work. The budgetary constraints are severe. Public spending on higher education is only .59 percent of GDP. Salary levels are extremely low, and competition from the private sector and from abroad transform into a Sisyphean labor the effort to build up teaching and research infrastructures and staff.

The new difficulties relate mainly to the government's claim that the UR must continue selling "knowledge services" to obtain revenues. This is easier said than done: the country spends only .25 percent of its GDP on re- search and development, and neither the state nor private enterprises have generated a strong demand for domestically created or applied knowledge. The UR is the only Uruguayan research university-in the Humboldtian sense-and produces 70 percent of all research done in Uruguay. The research function is especially important in a country like Uruguay, as it contributes to understanding the history and traditions of the nation, and of interpreting science and scholarship. The UR is basically the only research institution in the country and, as such, is of special importance.

A small nation like Uruguay cannot work its way out of underdevelopment without adding knowledge value to its production. That is why an "economicist" and shortterm view of public higher education that strangles its research function is a real danger for the country's future. Thus, a key political issue is to preserve and increase that function, as well as to encourage the whole society to become an active partner in the harnessing of knowledge to human development goals.

\section{International Higher Education On-line}

Beginning with this issue of International Higher Education, we are offering an important new innovationnow you can sign up to automatically receive notice of upcoming IHE publications. Sign-up is easy. Simply $\log$ on to our website <http://www.bc.edu/cihe> and follow the instructions in the middle of the page. Once signed on, you will receive the table of contents of each new IHE publication, with links to the full text of every article. This new service will put in you touch with our articles immediately on publication, will permit you to send our articles to colleagues, and allow you to communicate with us through the Internet.

You may not be aware that our on-line site also provides a comprehensive index of articles published in International Higher Education, to include links to the full text of each article. In this way, you can easily find past information concerning the countries, topics, and authors that have been previously published in IHE-a unique service valuable in research and policy analysis. In addition to the index, our website offers links to other higher education sites, to publications related to the Center for International Higher Education, and to additional information concerning higher education.

These initiatives are just a part of our effort to provide our readers with efficient electronic access to the latest information and analysis concerning higher education worldwide. The programs of the Center are supported by the Ford Foundation and by Boston College as a service to the university community. 